Tér és Társadalom 17. évf. 2003/1. 185-190. p.

Tér és Társadalom

XVII. évf. 2003 1: 185-212

\title{
VERSENYKÉPESSÉG
}

\section{AGRÁRTÉRSÉGEK KOMPLEX FEJLESZTÉSE}

\author{
(Complex Development of Agricultural Areas)
}

\author{
BUDAY-SÁNTHA ATTILA
}

Kulcsszavak:

agrártérség termōterület korszerü agrártermelés

A szerzó tanulmányában az agrártérségek hagyományos funkcioja, az élelmiszer és mezögazdasâgi (erdészeti) nyersanyagtermelése mellett bemutatja azokat a környezeti ártalmakkal túlterhelt világunkban nélkülözhetetlen, tulajdonképpen ,szolgáltatísnak" tekinthetó szolgálatokat, amelyeket a természet, az agrârtérségek nyújtanak a târsadalom számára. A "térgazdálkodás", "térfejlesztés" feladata, hogy az önmagukban is értéket képviseló természeti funkciók valamint a társadalmi, gazdasági igényeket kiszolgálo funkciók között egyensúlyt teremive a fejleszlés során a megfogalmazott prioritások mellett más potenciâlok is érvényesülhessenek. Az agrártérségek fejlödését is potitikai, gazdasági, társadalmi, természet- és környezetvédelmi szempontok, illetve érdekek befolyaisolják, a fejlesztésnek, a térhasználatnak azonban mindenképpen a térség fenntartható fejlódését kell szem elött tartania.

\section{A komplex térségfejlesztés föbb szempontjai és követelményei}

Agrártérségnek tekintjük mindazokat a területeket, amelyeket természetes vizek és összefüggő zöld felületek borítanak, így a fotoszintézis színterei, függetlenül attól, hogy az adott térség gazdaságában a mezógazdaság milyen súllyal szerepel. Ezeket a területeket a statisztika termöterületként tartja nyilván. Kiterjedésének meghatározása úgy történik, hogy az ország területéböl levonásra kerülnek a telepùlések belterületei, valamint a beépített ipari és üduilöterỉletek és az infrastruktúra (út, vasút) által elfoglalt térségek. 2001-ben az agrártérségek az ország területének 83,1\%-át foglalták el. Az agrártérség hagyományos funkciója a társadalom élelmiszer és mezögazdasági (erdészeti) nyersanyag-ellátása, de az urbánus és ipari területek súlyos szennyezettsége miatt ezek a területek biztosítják a természeti elemek (levegö, talaj, víz, élövilág) fennmaradásának, megújulásának, valamint az urbánus hatások által túlterhelt emberek rekreációjänak feltételeit is. Az ún. agrártérségek tehát több, egymáshoz szervesen kapcsolódó, összetartozó és a társadalom számára nélkülözhetetlen, ennek ellenére kelló szinten nem értékelt funkciót töltenek be. Veszélyeztetésük elsösorban abból adódik, hogy a társadalomnak nyújtott szolgáltatásaik többnyire nem piaci jellegüek, a társadalom azt ingyenes javakként élvezi, az agrártérségeknek ezeket a szolgáltatásokat magában foglaló számlája a nemzetgazdasági mérlegben nem jelenik meg. Ez azért is ellentmondásos, mert a térség által nyújtott rejtett funkciók mellett - ide sorolhatjuk az ember által okozott szennyezéseknek a levegőben, vízben, talajban, növényekben történő asszimilálását (nitrogén, 
$\mathrm{CO}_{2}$, szerves anyagok), megkötését (por), pufferolását (talaj), életfontosságú elemek kibocsátását $\left(\mathrm{O}_{2}\right)$ stb. - méreténél fogva ez a térség határozza meg az ország egészéröl kialakított képet, amely alapján egy társadalmat meg lehet és meg kell ítélni, mint egy háztartást a lakásáról.

Nem javítja a helyzetet az, hogy jelenleg egyetlen természeti elem, a föld van magántulajdonban, mely így piaci áruként "müködik”, azonban csak egyetlen funkciója, a mezögazdasági és erdögazdasági hozamai alapján, mintha a többi nem is létezne (vízmegőrzö, szolgáltató, élővilágot fenntartó, szennyezést megkötö funkciók). A mezőgazdaság, a mezőgazdasági termelés gazdasági-társadalmi leértékelödése ezért maga után vonja a föld, a talaj piaci értékvesztését, leértékelődését is. Ebböl adódik, hogy az agrártérség a más irányú társadalmi igények kielégítésére szabad térként jelenik meg, ahol sok esetben még a társadalom számára veszélyes anyagok, tevékenységek elhelyezése sem ütközik korlátokba, a társadalom etikai érzékét az nem sérti. Emiatt a települések, az ipar és infrastruktúra fejlesztésének, a hulladékok elhelyezésének, új nyersanyagkészletek feltárásának, üdülötelepek kialakításának a lehetöségét látja abban, hiszen úgymond a terület társadalmi értéke a jelenlegi használati mód mellett nem jelentös. A környezeti ártalmakkal túlterhelt világunkban, a 21. században, egy társadalom számára az egyik legnagyobb értéket valójában a rendelkezésére álló természetes, vagy természet közeli tér nagysága és állapota jelenti. Ebböl adódik, hogy annak megörzése, eröforrásainak pontos ismerete és az azzal való tudatos gazdálkodás alapvető társadalmi érdek.

Egy tér mindig többfunkciós, így a gazdálkodás során egyszerre kell az önmagukban értéket képviselö természeti funkciók, valamint a társadalmi, gazdasági igényeket kiszolgáló funkciók között egyensúlyt teremteni. A feladat valójában nem könynyủ, sőt rendkívül nehéz, mert minden igény kielégítése, az azt szolgáló funkciók elötérbe helyezése más funkciók érvényesülését korlátozza, gátolja. Másképpen fogalmazva minden térség egy meghatározott természeti, társadalmi, gazdasági potenciál-együttessel rendelkezik, és minden potenciál kihasználása bizonyos mértékben a többi potenciál csökkenésével jár. A lakótelepek kiterjesztése például nemcsak a természeti potenciál csökkenését okozza, de egyidejüleg kizár bizonyos ipari és infrastrukturális fejlesztéséket is, miközben másokat kifejezetten vonz. A "térgazdálkodás", "térfejlesztés" feladata, hogy a különbözö funkciók között egyensúlyt teremtve bizonyos fejlesztési prioritásokat úgy fogalmazzon meg, hogy az ne zárja ki más potencialok érvényesülését. És föleg ne járjon egy cél megvalósítása érdekében a térségi potenciál általános csökkenésével, mint azt számtalan ipari, bányászati, nehézipari célra igénybevett területen tapasztalni lehet. A természeti potenciál az, amelyre minden más potenciál, társadalmi igény épül. Így szinte minden más irányú fejlesztés annak a korlátozásával jár. Ezért e téren van szükség a legnagyobb körültekintésre és legtöbb kompromisszumra, mert ezen a téren a legkisebb az ellenállás, a társadalom jelenlegi fejlettségi szintjén a természeti elemeknek nincs, vagy csak nagyon korlátozott, áttételes az ,értékvédelme”.

Minden társadalomnak alapvetö, hosszú távú érdeke, hogy a rendelkezésére álló tér természeti funkciói mind tökéletesebben érvényesüljenek, tehát minél jobb le- 
gyen a területek vízmegörzö és víztisztító, vizszolgáltató, légtisztító, mikroklíma szabályozó képessége, talajainak termöképessége és élóvilágának gazdagsága, biodiverzitása. A „természetkövető” irányzat képviselői szerint ez a célkitüzés akkor teljesül a legnagyobb mértékben, ha minél több területet vonunk ki az emberi beavatkozás alól. Ez a feltétel a Föld azon térségeiben, ahol még magas a természetes vagy természet-közeli ökoszisztémák aránya és kicsi a népsürüség, igaz lehet, de már nem igaz ott, ahol magas a népsürüség, és a tájat több évszázadon vagy évezreden keresztül már emberi munka formálta. Nem lehet igaz egyrészt azért, mert a Föld legnagyobb részén a környezet fejlesztése már nem lehet független az ott élö emberektől, azok gazdasági, társadalmi tevékenységétől, másrészt pedig azért, mert az adott térségnek a természetvédelmi követelményeket egyoldalúan elötérbe helyező fejlesztése esetén sem egy valamikori, ősi állapot visszaállítása a cél, hanem az emberi beavatkozás hatására kialakult - a korábbitól lényegesen eltérő - természet-közeli, illetve félkultúr ökoszisztémák védelme, azok sajátos faji, tájképi értékeinek megőrzése. Ezek viszont nem stabil ökoszisztémák, emberi beavatkozás nélkül folyamatosan átalakulnak, és ezáltal a jelenlegi értékuiket elveszítik. Ezekben a térségekben nincs olyan terület, amely a jelenlegi formáját nem emberi beavatkozás hatására nyerte el, vagy azért, mert a használók bizonyos célból azt fontosnak tartották, illetve azért, mert azt elhanyagolták. Egy terület tehát azért gyep, erdő vagy mocsár, mert a terület használói úgy akarták, és ha így egy sajátos természeti érték jött létre, annak fenntartása is csak úgy képzelhetö el, ha a gyepet kaszálják, illetve legeltetik, a mocsarakat időnként kikotorják, vízellátását biztosítják, mert csak így biztosítható, hogy a természetes szukcessziós folyamatok ne érvényesíljenek, és a természeti adottságok alapján az erdö-övezetekben lévö gyepek be ne erdösüljének, és a mocsarak helyét se égeres erdök foglalják el.

Az agrártérségek fejlődését is politikai, gazdasági, társadalmi, környezet- és természetvédelmi szempontok befolyásolják. A több tényező, érdek ütközése következtében egy térség fenntartható fejlődése csak akkor biztosítható, ha a döntéseket

- a terület adottságainak pontos ismeretében hozzák meg;

- a fejlesztési célokat és azok megvalósulásához szükséges eszközöket a több tényező együttes figyelembevételével, komplexen határozzák meg;

- a fejlesztési feladatok megfogalmazása során a hosszú távú társadalmi érdekek érvényesülnek a rövid távú egyéni, illetve csoportérdekekkel szemben;

- a fejlesztési koncepciókat jövőorientáltan, a jövőbeni társadalmi igények, termelési feltételek figyelembevételével készítik el.

Az agrártérségek fejlesztésében napjainkig nem sikerült ezt a komplexitást megvalósítani, és ezért a fejlesztések is nem várt káros mellékhatásokkal jártak. Hazánkban az elmúlt évtized alapvetö, a térség sorsát befolyásoló politikai döntése a közösségi földtulajdoni formák felszámolása és a földek privatizálása volt. A döntés következménye: nagy tulajdonosi tömeg megjelenése, kis birtok és parcella méretek kialakulása, valamint a meglévő eszközállomány jelentős részének az elvesztése. A változás nem várt - bár elöre látható - káros következménye az, hogy a kellö tỏkével és piaci kapcsolatokkal, valamint megfelelő szakértelemmel nem rendelkező, 
gazdaságilag versenyképtelen kisgazdaságok termelési színvonala alacsony, termé- • keik minősége, élelmezés-egészségügyi megbízhatósága bizonytalan. A kis gazdasági méretük, az alacsony jövedelmezöségük nem teszi lehetővé, hogy hatékony technológiai megoldásokat alkalmazzanak. A termelés alacsony jövedelmezösége leértékeli a földet, eltereli a figyelmet a földvédelemröl, így annak leromlása (tápanyaghiány, elsavanyodás, erózió, defláció) folyamatossá vált. A területek mezőgazdasági funkciójának leértékelödése megnöveli a földkínálatot, és a földek más célra történö igénybevételének a lehetőségét, és ez a természeti potenciál csökkenésével jár. Igaz, hogy a földek értékvesztése megkönnyíti a természetvédelmi területek extenzív kiterjesztését is, de ezek a fenntartásukhoz szükséges pénzeszközök hiányában kedvezőtlenül átalakulnak, leromlanak.

Valójában minden egyoldalú döntés hasonló láncreakciót indít el, melynek a következményei kezdetben nehezen mérhetök fel, és csak az utólag jelentkező károk utalnak a hibákra. Azokat csak egy komplex, tervszerü fejlesztés elözheti meg. A területfejlesztés középpontjában az embernek, a társadalom hosszú távú érdekeinek kell állnia. Ez nincs ellentmondásban a természet védelmével, mert a társadalom érdeke, hogy a természeti erőforrásokat, a természeti értékeket megőrizze úgy, hogy egyidejủleg kielégíti más irányú igényeit is. Ebben az esetben az egyidejüség, a komplexitás a fontos.

\section{Az agrártérségek hasznositása}

Ha abból indulunk ki, hogy a természeti elemek önmagukban értéket képviselnek, akkor a legfontosabb feladat a természeti elemek érvényesülését, megújulását jelentö agrártérségek, ún. termöterületek csökkenésének megakadályozása, mérséklése. Mivel azonban a társadalom müködéséhez (települések, utak, szolgáltatások fejlesztése) ezekre a területekre is szükség van, nagyon lényeges, hogy a kivont terület minél kisebb legyen és minél kisebb környezeti potenciállal rendelkezö területre terjedjen ki, az lehetóleg ne károsítson ökológiai és mezögazdasági szempontból fontos élöhelyeket, termöterületeket. Nagyon fontos, hogy a települések fejlesztése elsősorban a beépített területek rehabilitációjával menjen végbe, és ne eredményezze a városok túlzott szétterülését, mert az - a természeti potenciál csökkenésével egyidejüleg - a gépkocsiforgalom növelésével tovább fokozza a városlakók káros környezeti terhelését (zaj, légszennyezés, rezgés) is.

További vitatott kérdés a megörzött agrártérségek további használata. Akörül nincs vita, hogy a kiemelt természeti értéket képezö, ún. magterületeknek és azok puffer területeinek legföbb funkciója a természeti értékek megőrzése, védelme. Ez sem könnyű feladat, mert gyakran a védett ökoszisztémák (pl. gyepek) is bizonyos használat (legeltetés, kaszálás) mellett tarthatók fenn, miközben a versenyképes gazdálkodás feltételei - a termelés korlátozása miatt - nem alakíthatók ki. Ezért a természetvédelem hatékonyságát nagymértékben befolyásolja az, hogy a korlátozások által okozott gazdasági hátrányokat a különböző támogatások ellensúlyozni 
tudják-e, illetve az itt mellékfunkció keretében elöállított, sajátos minöségú termékek piacra vitelét hogyan tudják megszervezni.

A területek többségének használati módját a területek talajainak termőképessége, mikroklímája és a környezetvédelem szempontjai döntik el. A mezőgazdaság gazdasági tevékenység, amelynél a hozamoknak piaci viszonyok között kell biztosítania a befektetett jelentős nagyságú tőke megtérülését és egyben a továbbfejlesztés feltételeit. Ez csak akkor teremthető meg, ha magas hozamok mellett, jó minőségü és az élelmezés-egészségügyi feltételeket kielégítỏ termékeket sikerül előállítani. Viszonyaink között szőlő- és gyümölcstermesztést, valamint szántóföldi művelést ezért csak a jobb adottságú területeken szabad folytatni. Erre a bizonytalan hozamok miatt nem alkalmasak a mélyen fekvő, vizenyős, valamint erősen lejtös és a száraz, homokos, vagy pedig sekély termörétegú területek. Ezek gyepként még kérỏdző állatokkal, kisebb ráfordítással, esetenként akár minimális ráfordítással, extenzív módon is hasznosíthatók, de akkor rendkívül kicsi, és a legeloállatok gazdasági pozíciójától függően nagyon bizonytalan a jövedelem, és alacsony a területek eltartóképessége. A gyepek gazdasági hasznosítása csak akkor jöhet szóba, ha olyan területi méretet érnek el, amely már lehetôvé teszi egy nagyobb állatállomány tartását. Viszonyaink között a területhasználatnak ezt a módját és annak sikerét alapvetően befolyásolja az, hogy a termelök a termelési kockázat mérséklésére milyen támogatásra számíthatnak. Annak hiányában a piacok telítettsége és a rendkívül éles verseny azt eredményezi, hogy a gyengébb minőségü, költségesebben müvelhetö területeken fel kell hagyni a mezögazdasági müveléssel. Kisebb, vízzel ellátott területeken elképzelhetỏ, hogy többcélú víztározókat, halastavakat létesítsenek, de a felszabaduló területek célszerü hasznosítási módja elsősorban azok beerdősítése lehet. A mezögazdasági területek feladása Magyarországon már hosszú ideje olyan gyors ütemü, hogy azzal az erdösités nem tud lépést tartani, ahhoz évente 20-25000 ha erdö telepítésére lenne szükség. Jelenleg az elmaradt erdősítések miatt 0,5 millió ha szántó-, szölö-, kert- és kb. 0,5-0,6 millió ha gyepterület áll használaton kívül. Ez azért kedvezötlen, mert a kultúrtáj képét rontja, az elszaporodó gyomok pollenje már népbetegséget okoz, és az elhagyott területeken rendszerint gyenge minőségü akácosok jönnek létre, ami nem kívánatos. Ezért ezeknek a területeknek a beerdősítésére van szükség őshonos fafajok felhasználásával, a gyengébb minőségü homoktalajokat pedig akáccal, fenyővel kell megkötni. Ma már egyre inkább különválik a 60-120 éves vágásfordulójú erdők telepítése, amelyekben több szintü erdei ökoszisztémák alakulnak ki, a 15-25 éves vágásfordulojú, kimondottan fatermelés céljára létrehozott nemesnyár és akác ültetvényektöl, amelyek azonban jelentős környezet- és természetvédelmi feladatot (erózió és defláció elleni védelem, élöhely stb.) is betöltenek.

Korunk jellemzöje, hogy miközben nö a természetvédelmi oltalomban részesített területek aránya, a továbbiakban nem elsösorban a természetvédelmi területek extenziv kibövitésére lenne szükség, hanem az agrártérségek egészének, az alkalmazott technológiáknak a környezetkímélö módon történö fejlesztésére. Ez a táj esetében azt jelenti, hogy azt kellően tagolják a mezőgazdasági területek, erdősávok, 
erdöfoltok és erdők, változatos élöhelyet biztosítva az élölényeknek, és egyben megfelelö védelmet teremtve a szél és a víz talajpusztító hatása ellen. A csökkenő arányú, mezőgazdaságilag hasznosított területek viszont úgy vannak kialakítva, hogy azokon a korszerủ agrotechnikai megoldásokat alkalmazni tudják, mert ezáltal lehet a legkisebb anyag- és energiafelhasználással és környezeti terheléssel piacképes termelést folytatni.

Súlyos tévedés az, amikor a környezetkímélö gazdálkodást valami primitív gazdálkodási formaként képzelik el. A korszerü agrártermelésnek a nagy szakértelemmel, magas müszaki színvonalon folyó, a helyi adottságokhoz illeszkedö, a gazdasági (piaci) humán-és állategészségügyi, higiéniai, környezet-és természetvédelmi, valamint az állatvédelmi követelményeknek megfelelö, a szántóföldtöl, illetve az istállótól a fogyasztó asztaláig minden szakaszában ellenórzött minöségi tömegtermelést tekintjük. Ami korunkban új, az az, hogy a minőség és tömeg nem ellentéte egymásnak, hanem feltételezi egymást, mert az élelmiszernek, mint bizalmi cikknek a termelése során fellépő sokrétủ követelményrendszernek, nem kevésbé a piacra jutásnak a magas költségeit csak egy megfelelö árutömeg viseli el. A korszerü agrártermelésnek két irányzata van: az integrált és a biotermesztés. Az integrált termelés alapvetöen profitorientált, piacközpontú termelési irány, amely az iparszerü, a hagyományos és a biotermesztés egyes elemeinek célszerú integrálásával árban versenyképes, garantált minőségü termékek előállítására törekszik. Ezzel szemben a biotermesztés elsősorban természetes anyagokra és természeti folyamatokra támaszkodó, a környezetvédelmi követelményekre kiemelt figyelmet fordító, sajátos minőségủ termékek előállítására törekvő termelési irányt jelent, azok számára, akik a magasabb termelési költséget a magasabb árakban meg tudják, és hajlandók is megfizetni. Mindkettő történhet extenzív és intenzív módon és mindkettő esetében a nagyobb termelési koncentráció piaci elönyt jelent, tehát egyik sem csak kisüzemi vagy nagyüzemi termelési forma. Középtávon a korszerü integrált és biotermesztés aránya 90:10\% körül alakulhat. Ezek a környezetkímélö termelési irányok már komoly figyelmet fordítanak a környezet- és természetvédelmi követelményekre, a táj ápoltságára, biomassza energia-termelésre és a rekreációt biztosító falusi turizmus feltételeinek a megteremtésére is.

\section{Irodalom}

Buday-Sántha A. (2001) Agrárpolitika - vidékpolitika. Dialóg Campus, Budapest-Pécs.

Buday-Sántha A. (2002) Környezetgazdálkodás. Dialóg Campus, Budapest-Pécs.

Csete L.-Harnos Zs.-Láng J. (1983) A magyar mezógazdaság agroökológiai potenciálja az ezredfordulón. Mezőgazdasági Kiadó, Budapest.

Enyedi Gy. (1983) Földrajzés társadalom. Magvetö Könyvkiadó, Budapest.

Gadó Gy.P. (szerk.) (2000) A természet romlása, a romlás természete Magyarországon. Föld Napja Alapítvány, Budapest.

Magyar Statisztikai Zsebkönyv 2001. (2002) KSH, Budapest. 